\title{
Erratum to: An adaptive composite density estimator for k-tree sampling
}

\author{
Steen Magnussen • Lutz Fehrman · William J. Platt
}

Published online: 20 May 2011

(C) Springer-Verlag 2011

Erratum to: Eur J Forest Res

DOI 10.1007/s10342-011-0502-8

There is an error in Table 1 of the original publication. In Row two (lambda_kv), Column three (Regressor, Constant) the value should be 0.70 (not 0.79 ).

The online version of the original article can be found under doi:10.1007/s10342-011-0502-8.

S. Magnussen ( $\square)$

Natural Resources Canada, Canadian Forest Service,

506 West Burnside Rd., Victoria, BC V8Z 1M5, Canada

e-mail: steen.magnussen@nrcan.gc.ca

L. Fehrman

Department of Forest Inventory and Remote Sensing, Faculty

of Forest Sciences and Forest Ecology, Georg-August-

Universität Göttingen, Büsgenweg 5, 37077 Göttingen, Germany

\section{W. J. Platt}

Department of Biological Sciences 202 LSB, Louisiana State

University, Baton Rouge, LA 70803, USA 